Chapman University

Chapman University Digital Commons

Athletic Training Faculty Articles and Research

Athletic Training

$11-1-2017$

\title{
Comparing Preceptor and Student Perceptions on Mentoring Characteristics: An Exploratory Study
}

Stephanie M. Mazerolle

University of Connecticut - Storrs

Jessica L. Barrett

University of Connecticut - Storrs

Christianne M. Eason

University of Connecticut - Storrs

Sara Nottingham

Chapman University, nottingh@chapman.edu

Follow this and additional works at: http://digitalcommons.chapman.edu/athletic_training_articles

Part of the Health and Physical Education Commons, Social and Philosophical Foundations of Education Commons, and the Sports Sciences Commons

\section{Recommended Citation}

Mazerolle, S.M., Barrett, J.L., Eason, C.M., \& Nottingham, S. (2016). Comparing preceptor and student perceptions on mentoring characteristics: An exploratory study. International Journal of Athletic Therapy and Training. doi: 10.1123/ijatt.2015-0066

This Article is brought to you for free and open access by the Athletic Training at Chapman University Digital Commons. It has been accepted for inclusion in Athletic Training Faculty Articles and Research by an authorized administrator of Chapman University Digital Commons. For more 


\section{Comparing Preceptor and Student Perceptions on Mentoring Characteristics: An Exploratory Study}

\section{Comments}

This article will be published in a forthcoming issue of the International Journal of Athletic Therapy and Training. The article appears here in its accepted, peer-reviewed form, as it was provided by the submitting author. It has not been copyedited, proofread, or formatted by the publisher. DOI: 10.1123/ijatt.2015-0066

\section{Copyright}

Human Kinetics 
"Comparing Preceptor and Student Perceptions on Mentoring Characteristics: An Exploratory Study"

Note. This article will be published in a forthcoming issue of the International Journal of Athletic Therapy and Training. The article appears here in its accepted, peer-reviewed form, as it was provided by the submitting author. It has not been copyedited, proofread, or formatted by the publisher.

Section: Article

Article Title: Comparing Preceptor and Student Perceptions on Mentoring Characteristics: An Exploratory Study

Authors: Stephanie M. Mazerolle ${ }^{1}$, Jessica L. Barrett ${ }^{1}$, Christianne M. Eason ${ }^{1}$, and Sara Nottingham ${ }^{2}$

Affiliations: ${ }^{1}$ Department of Kinesiology, University of Connecticut, Storrs, CT. ${ }^{2}$ College of Educational Studies, Chapman University, Orange, CA.

Journal: International Journal of Athletic Therapy and Training

Acceptance Date: October 17, 2016

(C)2016 Human Kinetics, Inc.

DOI: http://dx.doi.org/10.1123/ijatt.2015-0066 
"Comparing Preceptor and Student Perceptions on Mentoring Characteristics: An Exploratory Study"

by Mazerolle SM, Barrett JL, Eason CM, Nottingham S

International Journal of Athletic Therapy and Training

(C) 2016 Human Kinetics, Inc.

Comparing preceptor and student perceptions on mentoring characteristics: An exploratory study.

\section{Stephanie M. Mazerolle, PhD, ATC}

University of Connecticut, Assistant Professor Department of Kinesiology

She has directed the professional bachelor's program for over 9 years and is a content expert in professional workplace issues, professional socialization and clinical

education.

\section{Jessica L. Barrett, MSED, ATC}

University of Connecticut, Doctoral Student, Department of Kinesiology

Ms. Barrett recently completed her first year of doctoral studies at the University of

Connecticut. Her research interests include mentorship, professional socialization and clinical education.

\section{Christianne M Eason MS ATC}

University of Connecticut, Doctoral Candidate, Department of Kinesiology Ms. Eason is entering her 4th year as a Doctoral student at the University of Connecticut studying sport management. Her research interests include professional commitment and retention within athletic training, the work-life interface, and professional mentoring and role modeling.

\section{Sara Nottingham, EdD, ATC \\ Dr. Nottingham is an Assistant Professor and the Clinical Education Coordinator for the athletic training education program at Chapman University and conducts research on clinical education, preceptor-student interactions, and professional issues in athletic training}


"Comparing Preceptor and Student Perceptions on Mentoring Characteristics: An Exploratory Study"

by Mazerolle SM, Barrett JL, Eason CM, Nottingham S

International Journal of Athletic Therapy and Training

(c) 2016 Human Kinetics, Inc.

\section{Key Points}

- No significant differences exist in students and preceptors perceptions of mentoring.

- Preceptors and students value professional and interpersonal attributes of mentorship

- Gender and ethnicity were not highly rated aspects of mentorship.

Key Words: role models, socialization, role learning 
"Comparing Preceptor and Student Perceptions on Mentoring Characteristics: An Exploratory Study"

by Mazerolle SM, Barrett JL, Eason CM, Nottingham S

International Journal of Athletic Therapy and Training

(C) 2016 Human Kinetics, Inc.

\section{Introduction}

Mentors are a key resource for students, particularly as they traverse the socialization process into their future roles as a practitioner. ${ }^{1}$ Mentorship is described as a process for the informal transmission of knowledge, skills, attitudes, or beliefs between a more experienced person (mentor) and less experienced person (mentee). ${ }^{2}$ The relationship developed between the mentor and mentee is beneficial for role learning, and although it seems as though the relationship is unilateral it has been described as reciprocal and mutually beneficial for both parties. ${ }^{3-5}$ Due to their supervisory capacity and the nature of their role, preceptors often serve as mentors for athletic training students. Mentoring has become a universal practice for facilitating professional growth and development of students while they are being socialized into their future professional role. ${ }^{1-4}$

Indeed mentoring has been identified as helpful for student development, but new emerging data suggests mentoring also helps athletic trainers transition into a variety of roles including the graduate assistant, ${ }^{6,7}$ preceptor, ${ }^{8}$ doctoral student, ${ }^{9}$ and faculty member. ${ }^{10}$ In fact, preceptors who are identified as mentors by students often gain mentorship into their future roles from their previous supervisors. ${ }^{8}$ Development into a preceptor, however seems to take on a much more informal process, whereby student mentorship in clinical education may be more formalized. 5,8

Our understanding of what aspects are valued in a mentoring relationship is well understood. Broadly speaking, athletic trainers and students appear to value personal and professional characteristics along with educational dimensions. Personal characteristics include professionalism, approachability, and accessibility. Professional 
"Comparing Preceptor and Student Perceptions on Mentoring Characteristics: An Exploratory Study"

by Mazerolle SM, Barrett JL, Eason CM, Nottingham S

International Journal of Athletic Therapy and Training

(C) 2016 Human Kinetics, Inc.

characteristics include the ability to engage the mentee and facilitate growth in knowledge and skills. ${ }^{11}$ Educational dimensions include teaching skills and providing feedback. However often the information presented is from the perspective of the mentee or mentor individually, but never from the perspective simultaneously. Gaining this information concurrently can lead to data triangulation, and provide more substantive information on what students and preceptors' value in the mentoring relationship that has been deemed so critical in professional development. ${ }^{1-4}$ Thus, our purpose was to explore and compare the perspectives of athletic training students and preceptors on what aspects of the mentoring relationship they value, as previously described by Pitney et al. ${ }^{12}$ The following central questions guided the study:

1. Do athletic training students and preceptors value the same characteristics in their mentoring relationships?

2. What values do athletic training students and preceptors perceive to be most important in mentoring relationships?

\section{Methods}

We used an exploratory, mixed-method design ${ }^{13}$ to discover the perceptions of our participants in regards to what they value in a mentor. We collected the data simultaneously, that is the survey instrument and open-ended questions were presented concurrently, in order to connect our findings to our research questions. ${ }^{13}$ Both the survey and open-ended questions were administered via Qualtrics, an online survey platform, and participants were asked to respond to the open-ended questions in a written response. Our research design also reflected collecting the same information (each asked 
"Comparing Preceptor and Student Perceptions on Mentoring Characteristics: An Exploratory Study"

by Mazerolle SM, Barrett JL, Eason CM, Nottingham S

International Journal of Athletic Therapy and Training

(C) 2016 Human Kinetics, Inc.

same set of questions) from both the preceptor and student on the role of mentoring in clinical education.

\section{Participants}

We purposefully recruited preceptors and athletic training students from 7 Commission on Accreditation of Athletic Training Education accredited undergraduate

professional preparation athletic training programs. In total we had 29 participants (12 preceptors, 17 students) complete the study. Our preceptors included 5 males and 7 females, from 4 different National Athletic Trainers' Association districts, were $32 \pm 10.5$ years of age, with an average of $5 \pm 5.0$ years experience as a preceptor. The athletic training students (ATSs) on average were $21 \pm 1$ years old and represented varying levels of academic standing ( 1 sophomore, 9 juniors, 7 seniors). The ATSs (14 female and 3 male) had all completed at least 1 clinical education experience and had been enrolled in their program an average of $3 \pm 1.7$ semesters at the time of data collection. All 29 participants indicated they currently had or have had a mentor. Mentors identified by our sample were those individuals working in the field such as a preceptor, peer athletic trainer, or supervising athletic trainer.

\section{Instrumentation}

Our study used the validated Athletic Training Perceptions of Effective Mentoring Survey (ATSPME) ${ }^{12}$ along with several open-ended questions. The ATSPME has a Cronbach's a .85 among athletic training students, and scored a .612 (preceptors) and .806 (students) for our sample group. The 4-part survey directly asks participants if they 
"Comparing Preceptor and Student Perceptions on Mentoring Characteristics: An Exploratory Study"

by Mazerolle SM, Barrett JL, Eason CM, Nottingham S

International Journal of Athletic Therapy and Training

(C) 2016 Human Kinetics, Inc.

have a mentor and whom that mentor is, after reviewing an operational definition. The operational definitions of mentoring, mentor and mentee were as follows ${ }^{12}$ :

Mentoring: A one-one-one relationship whereby an experienced and concerned individual takes an interest in and actively helps a less experienced individual develop his/her potential.

Mentor: An experienced individual who is in a relationship with a protégé and assists in his/her development.

Mentee: A less experienced individual who is in a relationship with a mentor and benefits by developing his/her potential.

The subsequent aspects of the study ask the participants to evaluate mentoring roles they feel are important. The scale was anchored using a 5-point Likert scale $(1=$ strongly disagree to 5 = strongly agree). All open-ended questions were centered on mentoring roles and valued aspects of the mentoring experience ${ }^{11,12}$ as well as professional development and clinical education. ${ }^{14,15}$ We completed a peer review of our interview guide as well as a pilot study with 2 preceptors and 2 students, prior to launching our full data collection procedures. The pilot participants age and years of experience were similar to those of the target population. No changes were made based upon the pilot, therefore pilot data was included in the analyses.

\section{Data Collection Procedures}

We initiated participant recruitment after IRB approval was secured and followed a purposeful, criterion sampling procedure. ${ }^{16}$ Recruitment of participants was completed through colleagues who serve in the role of clinical education coordinators. The clinical 
"Comparing Preceptor and Student Perceptions on Mentoring Characteristics: An Exploratory Study"

by Mazerolle SM, Barrett JL, Eason CM, Nottingham S

International Journal of Athletic Therapy and Training

(C) 2016 Human Kinetics, Inc.

coordinators were asked to assist in dissemination of the participant recruitment email. We requested the clinical coordinators forward an email to those students and preceptors meeting our inclusion criteria, the email included a link to the survey along with a description of the study, informed consent and details of participation. Email invitations were sent to potential participants who were currently engaged in clinical education and had at least one full year of experience in that role (either as a preceptor or as a student) during the Fall 2014 academic semester. Agreement to participate and consent was granted by completion of the online questionnaire (Qualtrics, Provo, UT). We sent two follow-up emails at one-week and 3-weeks post the original email to aid in data collection. In total, clinical coordinators reported to the researchers they forwarded the email invitations and reminders to 45 preceptors and 52 students directly, resulting in a $30 \%$ $(n=29 / 97)$ response rate.

\section{Data Analysis}

Due to our small sample size, we calculated Hedges' g effect size and confidence intervals. Independent sample $t$ tests were performed to compare the mean scores of athletic training students and preceptors perceptions of mentoring as assessed using the ATSPME. Two researchers independently completed multiple readings of the transcripts and coded the qualitative data following a general inductive approach, as described by Thomas. ${ }^{17}$ Specifically, we were able to identify emergent themes from the data, using a multiple read through system; a key aspect to inductive analyses. Additionally, general inductive approach allows for the researchers to organically develop codes, permitting for the most emergent themes to surface. ${ }^{17}$ We completed this process independently from 
"Comparing Preceptor and Student Perceptions on Mentoring Characteristics: An Exploratory Study"

by Mazerolle SM, Barrett JL, Eason CM, Nottingham S

International Journal of Athletic Therapy and Training

(C) 2016 Human Kinetics, Inc.

the analyses performed with the ATSPME data. We labeled our data with codes, then with each read, we were able to group similar concepts together, and only included those codes which were predominant within the final schematics. Each substantive read by the two researchers allowed for a better understanding of the key themes, which were used to match the analyses ran examining the Likert-scaled data from the ATSPME. The triangulation resulted in the findings presented below, and included the discussions of appropriate terminology for the themes, and data included to support them. The mixedmethod design provided an inherent triangulation of the data. This used in combination with multiple researcher triangulation, allowed us to determine creditability of the data. Additionally, using the guidelines of the general inductive approach ${ }^{17}$ only themes that represented the majority of our participant's experiences were included in the final presentation. Our coding process determined saturation was met, after completing the inductive coding process.

\section{Results}

The research questions that guided the study were: 1) Do athletic training students and preceptors value the same characteristics in their mentoring relationships?, and 2) What values do athletic training students and preceptors value in their mentoring relationships? Nine (9) items from the ATSPME had highly rated and comparable scores for both participant groups (Table 1) while three scale items had low rated comparable scores (Table 2). The Hedges' $g$ effect size and confidence intervals can be found in Table 1 and Table 2. No significant differences were found between the mean scores of athletic training students and preceptors' perceptions of mentoring on nine of the 12 
"Comparing Preceptor and Student Perceptions on Mentoring Characteristics: An Exploratory Study"

by Mazerolle SM, Barrett JL, Eason CM, Nottingham S

International Journal of Athletic Therapy and Training

(C) 2016 Human Kinetics, Inc.

questions assessed using the ATSPME. The Hedges' $g$ effect size for these items were

less than 0.39 (Table 1), indicating that non-significant results were not a result of small sample size. Independent t-tests also revealed the three items that had low comparable scores (Table 2) were also not statistically different. However, the Hedges' g effect size indicates there is a possibility that these results were impacted by sample size. The highest rated items included those based on aspects of support, encouragement, feedback, advice, brainstorming, role modeling, listening skills, communication and trust. Relating specifically to the unimportant values, the items of gender and ethnicity impacting mentoring relationships were the two lowest rated items for both groups.

Our inductive analysis of the open-ended interview questions revealed 3 themes evident in the participant's responses regarding mentoring relationships, 1) Ongoing Support, 2) Role Modeling, 3) Interpersonal Characteristics. We present textual data from our participants' responses to the open-ended interview questions in Table 1 to further support the findings. The data is located in the final column of the Table.

\section{Discussion}

ATSs and preceptors have similar values in characteristics related to mentoring. The trends identified in the nine highly rated items from the ATSPME aligned with the qualitative themes that were identified from the open-ended interview questions, noted similarities exist between the values of the two groups. Preceptors and students identified many of the same values as important and unimportant for mentoring relationships. The three themes evident in the participants open-ended interview questions were linked to the ATSPME in the following way: 
"Comparing Preceptor and Student Perceptions on Mentoring Characteristics: An Exploratory Study"

by Mazerolle SM, Barrett JL, Eason CM, Nottingham S

International Journal of Athletic Therapy and Training

(C) 2016 Human Kinetics, Inc.

1) Ongoing Support: this was described as a mentor's role in supporting the mentee and was done through understanding, encouragement and providing feedback. Four items of support, encouragement, feedback, advice from the ATSPME linked to this theme.

2) Role Modeling: participants recounted learning their professional behaviors and attitudes from their mentors and modeling the practices of their mentors. Two items of brainstorming/facilitating ideas and role modeling from the ATSPME linked to this theme.

3) Interpersonal Characteristics: these characteristics included communication, specifically listening skills as well as personal attributes such as trust and empathy. There were three items from the ATSPME, listening skills, communication and trust, which linked to this theme.

Our study yielded comparable findings to the work of Pitney et al. ${ }^{8}$ regarding valued characteristics of a mentoring relationship. Gender and ethnicity were not highly rated aspects of mentorship, for our sample, as also found by Pitney et al. ${ }^{12}$ in a sample of athletic training students. ${ }^{12}$ This result indicates these developmental relationships are founded more on professional attributes, rather than identifying demographic characteristics. For our sample, the educational, motivational, relational, and counseling attributes of a mentoring relationship appeared to be more of value than others. This indicates both preceptors and athletic training students value the professional and interpersonal attributes possessed by their mentors. We do however recognize our sample was predominately female, which could explain the lack of differences. Our sample was much like the work of Pitney et $\mathrm{al}^{12}$ which included more female athletic training students than males. 
"Comparing Preceptor and Student Perceptions on Mentoring Characteristics: An Exploratory Study"

by Mazerolle SM, Barrett JL, Eason CM, Nottingham S

International Journal of Athletic Therapy and Training

(C) 2016 Human Kinetics, Inc.

Professional attributes include being a good role model, demonstrating professionalism, being respected as an athletic trainer, and possessing knowledge and skills that can help facilitate learning for the mentee. ${ }^{11,12,18}$ Mentoring is founded on the premise that learning will take place, thus as Pitney and Ehlers ${ }^{11}$ determined, there is an educational aspect of the relationship. Within the educational dimension of mentoring, there is facilitation of knowledge and skills by engaging the mentee, providing feedback, and encouraging professional discourse. ${ }^{11}$ Brainstorming, feedback, and serving as a role model were all ranked as important for our sample; aspects of a professional, yet educational relationship.

The personal characteristics of a mentor can be summarized simply by strong interpersonal skills, approachability, openness, trust, involvement, and engaging. ${ }^{11,12,19}$ Such foundational behaviors have been recommended when selecting preceptors to supervise students in clinical education ${ }^{14}$ and were reported as helpful characteristics for students engaged in learning. ${ }^{15}$ Our sample, much like the work of others examining mentoring relationships, ${ }^{11,12}$ found mentees want a mentor who can be supportive, communicative, trustworthy, as well as a mentor who provides guidance.

\section{Limitations}

Our sample, by design, was small. Using a mixed-methods approach we wanted to explore the experiences of preceptors and students regarding mentoring relationships. Previous research has examined these groups independently and often used a single method approach of either quantitative or qualitative alone. Thus, our results can only speak to the experiences of our participants, but do yield insights on what the preceptor 
"Comparing Preceptor and Student Perceptions on Mentoring Characteristics: An Exploratory Study"

by Mazerolle SM, Barrett JL, Eason CM, Nottingham S

International Journal of Athletic Therapy and Training

(C) 2016 Human Kinetics, Inc.

and student value in their mentor. Although the ATSMPE survey yielded respectful Cronbach scores in previous research and with our students, the score was suspect with the preceptors. A more robust sample will allow for greater comparisons, as well as a likely improved score for reliability. Also, our sample reflects a small number of males, and although we did not compare responses based upon gender differences this could impact our findings. Additionally, we did not report differences with ethnicity and mentors, yet we did not collect this information to make comparisons.

\section{Clinical Implications}

Our data uniquely contributes to the existing literature, in regards to demonstrating that regardless of the role assumed, valued characteristics in mentoring are similar between preceptors and ATs. The present study has added further credibility to the importance of mentors demonstrating professional elements such as role modeling and professionalism as well as interpersonal skills of openness, availability and trust. Therefore, any professional in a mentoring role should strive to emulate those characteristics. Clinical education coordinators need not worry about matching identifying traits such as gender or ethnicity between preceptors and students but instead should focus on instructing preceptors to embody the valued professional and interpersonal traits. Athletic trainers who wish to be mentors should continuously work to personify these ideal mentoring characteristics.

\section{Future Research}

To further this research a larger sample size that incorporates the preceptor and student to make comparisons in their perceptions of important mentoring characteristics 
"Comparing Preceptor and Student Perceptions on Mentoring Characteristics: An Exploratory Study"

by Mazerolle SM, Barrett JL, Eason CM, Nottingham S

International Journal of Athletic Therapy and Training

(C) 2016 Human Kinetics, Inc.

needs to be conducted. We also believe future research should be longitudinal including both preceptors and students, as means to observe how the connection can grow and change over the course of the relationship. The premise behind mentoring is that a lifelong relationship is forged; yet most literature only examines the relationship as a reflection of the experience. Thus, tracking the development of mentoring relationships over the course of a semester or academic year could yield further insights. Future studies could examine gender differences among perceptions of mentoring. Future research can continue to examine multiple factors related to mentorship, including but not limited to years of experience engaged as a preceptor, number of students supervised (in total, and concurrently during clinical experience), academic standing, and expectations for mentoring. 
"Comparing Preceptor and Student Perceptions on Mentoring Characteristics: An Exploratory Study"

by Mazerolle SM, Barrett JL, Eason CM, Nottingham S

International Journal of Athletic Therapy and Training

(C) 2016 Human Kinetics, Inc.

\section{References}

1. Shen J, Spouse J. Learning to nurse in china - structural factors influencing professional development in practice setting: A phenomenological study. Nurse Education in Practice. 2007;7:323-332.

2. Bozeman B, Feeney MK. Toward a useful theory of mentoring: A conceptual analysis and critique. Administration and Society. 2007;39(6):719-739.

3. Stewart BM, Krueger LE. An evolutionary concept analysis of mentoring in nursing. $J$ Prof. 1996;12(5):311-321.

4. Kram KE. Phases of the mentor relationship. Academy of Management Journal. 1983;26(4):608-625.

5. Nottingham SL, Barrett JL, Mazerolle SM, Eason CM. Examining the role mentorship plays in the development of athletic training preceptors. Athletic Training Education Journal. In Review.

6. Mazerolle SM, Eason CM, Clines S, Pitney WA. The professional socialization of the graduate assistant athletic trainer. J Athl Train. 2015;50(5):532-541.

7. Thrasher AB, Walker SE, Hankemeier DA, Pitney WA. Supervising athletic trainers' perceptions of professional socialization of graduate assistant athletic trainers in the collegiate setting. . J Athl Train. 2015;50(3):321-333.

8. Mazerolle SM, Bowman TG, Dodge TM. The professional socialization of the athletic trainer serving as an approved clinical instructor. J Athl Train. 2014;49(1):75-82.

9. Bowman TG, Mazerolle SM, Klossner JK. The professional socialization of doctoral students seeking careers in athletic training. . 2015;Oral Presentation.

10. Mazerolle SM, Bowman TG, Klossner JC. An analysis of doctoral students' perceptions of mentorship during their doctoral studies. Athl Train Educ J. 2015;10(3):227-235.

11. Pitney WA, Ehlers GG. A grounded theory study of the mentoring process involved with undergraduate athletic training students. J Athl Train. 2004;39(4):344-351.

12. Pitney WA, Ehlers GE, Walker SE. A descriptive study of athletic training students' perceptions of effective mentoring roles. Internet Journal of Allied Health Science and Practice. 2006;4(2):1-8.

13. Clark V, Creswell J. The mixed methods reader. Los Angeles: Sage; 2008.

14. Weidner TG, Henning JM. Development of standards and criteria for the selection, training, and evaluation of athletic training approved clinical instructors. J Athl Train. 2004;39(4):335-343. 
"Comparing Preceptor and Student Perceptions on Mentoring Characteristics: An Exploratory Study"

by Mazerolle SM, Barrett JL, Eason CM, Nottingham S

International Journal of Athletic Therapy and Training

(C) 2016 Human Kinetics, Inc.

15. Curtis N, Helion J, Domsohn M. Student athletic trainer perceptions of clinical supervisor behaviors- A critical incident study. J Athl Train. 1998;33(3):249-253.

16. Pitney W, Parker J. Qualitative research in physical activity and the health professions. Champaign, IL: Human Kinetics; 2009.

17. Thomas D. A general inductive approach for qualitative data analysis. American Journal of Evaluation. 2006;27:237-246.

18. Jokelainen $\mathrm{M}$, Turunen $\mathrm{H}$, Tossavainen $\mathrm{K}$, Jamookeeah $\mathrm{D}$, Coco K. A systematic review of mentoring nursing students in clinical placements. Journal of Clinical Nursing. 2011;20:2854-2867.

19. Pritchard E, Gidman J. Effective mentoring in the community setting. British Journal of Community Nursing. 2012;17:119-124. 
Table 1. Highly Rated Comparable Results

\begin{tabular}{|c|c|c|c|c|c|}
\hline \multirow{2}{*}{$\begin{array}{l}\text { Mentor } \\
\text { Question }\end{array}$} & \multirow{2}{*}{$\begin{array}{c}\text { Student } \\
(\mathrm{n}=17) \\
\text { Likert Scale } \\
\text { Mean Score }\end{array}$} & \multirow{2}{*}{$\begin{array}{l}\text { Preceptor } \\
(n=12) \\
\text { Likert } \\
\text { Scale } \\
\text { Mean } \\
\text { Score }\end{array}$} & \multicolumn{2}{|l|}{ Hedges' g } & \multirow[t]{2}{*}{ Quotes, pseudonyms } \\
\hline & & & effect size & $\begin{array}{l}\text { Confidence } \\
\text { interval }\end{array}$ & \\
\hline \multicolumn{6}{|c|}{ Theme of Ongoing Support } \\
\hline $\begin{array}{l}\text { An effective } \\
\text { mentor is } \\
\text { supportive of a } \\
\text { protégé. }\end{array}$ & $4.67 \pm .48^{* *}$ & $4.75 \pm .45$ & -0.17 & $-0.91-0.57$ & $\begin{array}{l}\text { "Important that young ATs feel supported and have } \\
\text { someone who can continue to assist them outside the } \\
\text { classroom." - Rose, preceptor } \\
\text { "My mentors have been supportive and encouraging of my } \\
\text { career goals. Whenever I get discouraged they tell me all } \\
\text { the ways that I have been successful and focus on the } \\
\text { positives rather than the negatives." - Dakota, student }\end{array}$ \\
\hline $\begin{array}{l}\text { An effective } \\
\text { mentor } \\
\text { encourages a } \\
\text { protégé. }\end{array}$ & $4.76 \pm .43^{* *}$ & $4.75 \pm .45$ & 0.02 & $-0.72-0.76$ & $\begin{array}{l}\text { "An ideal mentor is not belittling or condescending, but } \\
\text { encouraging." - Ellie, preceptor } \\
\text { [An ideal mentor is] “Understanding, tells you what you } \\
\text { need to hear without being negative. Encouraging and } \\
\text { supportive." - Jamie, student }\end{array}$ \\
\hline $\begin{array}{l}\text { An effective } \\
\text { mentor gives } \\
\text { feedback to a } \\
\text { protégé about } \\
\text { his/her } \\
\text { performance as } \\
\text { an athletic } \\
\text { training student. }\end{array}$ & $4.62 \pm .74$ & $4.66 \pm .49$ & -0.06 & $-0.80-0.68$ & $\begin{array}{l}\text { "The mentor provides constructive feedback to the mentee } \\
\text { and allows him/her to reflect on it and repeat the skill } \\
\text { again." - Katie, preceptor } \\
\text { "I have made my skills better and better by working at } \\
\text { clinical sites and getting feedback from my mentors." - } \\
\text { Quinn, student }\end{array}$ \\
\hline
\end{tabular}




\begin{tabular}{|c|c|c|c|c|c|}
\hline \multirow{2}{*}{$\begin{array}{l}\text { Mentor } \\
\text { Question }\end{array}$} & \multirow{2}{*}{$\begin{array}{c}\text { Student } \\
(\mathrm{n}=17) \\
\text { Likert Scale } \\
\text { Mean Score }\end{array}$} & \multirow{2}{*}{$\begin{array}{c}\text { Preceptor } \\
\text { (n = 12) } \\
\text { Likert } \\
\text { Scale } \\
\text { Mean } \\
\text { Score }\end{array}$} & \multicolumn{2}{|l|}{ Hedges'g } & \multirow[t]{2}{*}{ Quotes, pseudonyms } \\
\hline & & & effect size & $\begin{array}{l}\text { Confidence } \\
\text { interval }\end{array}$ & \\
\hline $\begin{array}{l}\text { An effective } \\
\text { mentor gives } \\
\text { helpful advice. }\end{array}$ & $4.76 \pm .43^{* *}$ & $4.83 \pm .38^{* *}$ & -0.17 & $-0.91-0.57$ & $\begin{array}{l}\text { "Perhaps they have more experience than you so they can } \\
\text { offer sound advice." - Rose, Preceptor } \\
\text { "My current mentor has been my favorite mentor during my } \\
\text { education because he is constantly challenging me, gives me } \\
\text { advice, and constantly gives me positive and negative } \\
\text { feedback." - Reese, student }\end{array}$ \\
\hline \multicolumn{6}{|c|}{ Theme of Role Modeling } \\
\hline $\begin{array}{l}\text { An effective } \\
\text { mentor should } \\
\text { facilitate } \\
\text { brainstorming } \\
\text { and stimulate } \\
\text { ideas. }\end{array}$ & $4.65 \pm .58^{*}$ & $4.66 \pm .49$ & -0.02 & $-0.77-0.73$ & $\begin{array}{l}\text { "[students] need to be involved with clinical decision } \\
\text { making processes as much as possible and developing a } \\
\text { good relationship with a mentor can help that." - Ben, } \\
\text { preceptor } \\
\text { "Having a mentor has helped me to broaden my thoughts } \\
\text { about my capabilities and to challenge myself more." - } \\
\text { Dakota, student }\end{array}$ \\
\hline $\begin{array}{l}\text { An effective } \\
\text { mentor is a good } \\
\text { role model. }\end{array}$ & $4.76 \pm .43$ & $4.91 \pm .28$ & -0.39 & $-1.13-0.36$ & $\begin{array}{l}\text { "Having a mentor is great. It helps you strive for qualities } \\
\text { that you think are going to make you a great athletic } \\
\text { trainer." - Lynn, Preceptor } \\
\text { "The mentor should be the role model, example, and proof } \\
\text { of success through hard work and perseverance." - } \\
\text { Lennon, student }\end{array}$ \\
\hline
\end{tabular}




\begin{tabular}{|c|c|c|c|c|c|}
\hline \multirow{2}{*}{$\begin{array}{l}\text { Mentor } \\
\text { Question }\end{array}$} & \multirow{2}{*}{$\begin{array}{c}\text { Student } \\
(\mathrm{n}=17) \\
\text { Likert Scale } \\
\text { Mean Score }\end{array}$} & \multirow{2}{*}{$\begin{array}{l}\text { Preceptor } \\
\text { (n= 12) } \\
\text { Likert } \\
\text { Scale } \\
\text { Mean } \\
\text { Score }\end{array}$} & \multicolumn{2}{|l|}{ Hedges' g } & \multirow[t]{2}{*}{ Quotes, pseudonyms } \\
\hline & & & effect size & $\begin{array}{l}\text { Confidence } \\
\text { interval }\end{array}$ & \\
\hline \multicolumn{6}{|c|}{ Theme of Interpersonal Characteristics } \\
\hline $\begin{array}{l}\text { Effective } \\
\text { mentoring } \\
\text { requires good } \\
\text { listening skills. }\end{array}$ & $4.86 \pm .35$ & $4.75 \pm .45^{* *}$ & 0.27 & $-0.47-1.01$ & $\begin{array}{l}\text { "They should be a good listener and be open to } \\
\text { constructive criticism" - Lauren, preceptor } \\
\text { "An ideal mentor is someone who is a great listener. They } \\
\text { have to be able to listen to your problems and stories and not } \\
\text { only be focused on themselves." - Casey, student }\end{array}$ \\
\hline $\begin{array}{l}\text { An effective } \\
\text { mentor needs to } \\
\text { be a good } \\
\text { communicator. }\end{array}$ & $4.62 \pm .49$ & $4.75 \pm .45^{* *}$ & -0.27 & $-1.01-0.48$ & $\begin{array}{l}\text { [An ideal mentor is] "Able to listen and communicate with } \\
\text { the mentee so he/she can figure out the best way to be a } \\
\text { mentor." - Derek, preceptor } \\
\text { [An ideal mentor] "Should be open to communication." - } \\
\text { Jessie, student }\end{array}$ \\
\hline $\begin{array}{l}\text { Effective } \\
\text { mentoring is } \\
\text { based on trust. }\end{array}$ & $4.62 \pm .49$ & $4.58 \pm .51$ & 0.08 & $-0.66-0.82$ & $\begin{array}{l}\text { [An ideal mentor is] "trustworthy" - Mark, preceptor } \\
\text { "It is extremely important that the protege can trust their } \\
\text { mentor and feel comfortable with them, especially when } \\
\text { they need to discuss any problems they might have." - } \\
\text { Jessie, student }\end{array}$ \\
\hline
\end{tabular}

*16 of 17 students answered question

**Although detailed here, some likert data (5 point scale, $\mathbf{1}=$ strongly disagree to $\mathbf{5}=$ strongly agree) is also included in one other article published from this study [blinded citations] 
"Comparing Preceptor and Student Perceptions on Mentoring Characteristics: An Exploratory Study"

by Mazerolle SM, Barrett JL, Eason CM, Nottingham S

International Journal of Athletic Therapy and Training

(C) 2016 Human Kinetics, Inc.

Table 2: Low Rated Comparable Results

\begin{tabular}{|c|c|c|c|c|}
\hline \multirow[b]{2}{*}{ Mentoring Question } & \multicolumn{2}{|c|}{ Likert Scale Mean Score* } & \multicolumn{2}{|c|}{ Hedges' g } \\
\hline & $\begin{array}{c}\text { Student } \mathrm{n}= \\
17\end{array}$ & $\begin{array}{c}\text { Preceptor } \mathbf{n}= \\
12\end{array}$ & Effect size & $\begin{array}{c}\text { Confidence } \\
\text { interval }\end{array}$ \\
\hline $\begin{array}{l}\text { Mentoring is more } \\
\text { effective when a mentor is } \\
\text { the same ethnicity as the } \\
\text { protégé. }\end{array}$ & $2.0 \pm .94$ & $1.5 \pm .66$ & 0.58 & $-0.17-1.33$ \\
\hline $\begin{array}{l}\text { Mentoring is more } \\
\text { effective when the mentor } \\
\text { and the protégé are of } \\
\text { similar ages. }\end{array}$ & $2.2 \pm .87$ & $1.7 \pm .96$ & 0.54 & $-0.22-1.29$ \\
\hline $\begin{array}{l}\text { Mentoring is more } \\
\text { effective when a mentor is } \\
\text { the same gender. }\end{array}$ & $2.2 \pm .99$ & $1.7 \pm .65$ & 0.56 & $-0.19-1.31$ \\
\hline
\end{tabular}

*5 point Likert Scale $(1=$ strongly disagree, 5 = strongly agree $)$ 